\title{
ASSESSMENT OF CLIMATE EFFECT ON EGYPTIAN AGRICULTURE: AN EFFICIENCY ANALYSIS APPROACH
}

\author{
F. Abdelradi \\ Corresponding Author: Department of Agricultural Economics - Faculty of Agriculture - \\ Cairo University, 3 Gamaa street, P.O.: 12613, giza, Egypt \\ E-mail: fadi.abdelradi@agr.cu.edu.eg
}

Received: Feb. 23, 2020

Accepted: Mar. 1, 2020

\begin{abstract}
The Intergovernmental Panel on Climate Change (IPCC) 2018 special report on the implications of 1.5 degrees warming (SR 1.5) concludes that the expected impacts of the 2 degrees' increase are more critical than expected leading to imminent critical tipping points. Additionally, the report indicates that there is a window of only 12 years to take actions to achieve the 1.5 degrees' target. While Africa is contributing the least to global warming by $4 \%$ of global greenhouse-gas emissions, it is one of the vulnerable regions to Climate Change (CC) effects. The objective of this study is to assess different climatic variables on the technical efficiency of the cereal crops production in the largest five producing governorates in Egypt. This objective will be achieved through using panel frontier model to assess the impact of average maximum temperature, humidity and solar radiation on the wheat, rice and maize producing governorates. Results of the analysis show that the average maximum temperature and humidity contribute to worsening the technical efficiency of the cereals producers.
\end{abstract}

Key words: Climate change, frontier, efficiency analysis, Egypt, panel data

\section{INTRODUCTION}

Both agriculture and CC affect each other. CC affects agriculture in different ways through changing the intensity, the frequency, and occurrence of events (rainfall, heat waves, changes in pests and diseases, changes in carbon dioxide, droughts) that are not common in the location's history. For example, the increased temperature has contributed to changes to growing seasons affecting the flowering and harvesting of crops. Agriculture produces Greenhouse Gases emissions (GHGs) due to the practices of conventional food production systems (Olila et al., 2016). Additionally, according to the World Bank report (World Bank report, 2016). CC and poverty reduction are major issues to the international society; furthermore, the challenges of food and nutrition security in developing countries are increasing (FAO report, 2016). As a result, the need for innovative and resilient agricultural production practices to cope with these factors is essential. Climate Smart Agriculture (CSA) is an approach that deals with restructuring agricultural systems to cope with CC through three main objectives, which are sustainability increasing productivity and incomes, mitigating GHG emissions, adaptation and building resilience.

\section{Importance of study and research problem}

Egypt faces many food and nutrition security challenges despite the rich agricultural resources, for example, the high levels of food losses experienced in all value chain with an average of $35 \%$ based on the FAOSTAT food balance sheet (FAOSTAT, 2018). These, in part, due to the low capability for efficient use of these resources, inefficient policies, poor labor skills, poor market dynamics, 
inefficient market information systems, increasing intensity of climate change, poverty, dependence on rainfall for irrigation, poor infrastructure (IFPRIWFP, 2013). Historically, Egyptian agroecological systems recognized the importance of trees within and outside the farm for climate and livelihood improvement and as such endeavored to preserve a specific type of species through cultivation to harvest. However, present stagnation and/or reduction in the number of trees on and around farmland (Zomer et al., 2016), as well as water scarcity in Egypt, contribute to low agricultural production and increasing environmental degradation which is detrimental to agrarian livelihoods (food, feed, energy, and material demand). Furthermore, faced with growing local demand and competition for resources, Egypt's food production needs to analyze in a wider context, affecting $50 \%$ of the population lives in rural areas, through finding synergies among agriculture, energy, water and ecosystem.

According to the (FAO report, 2016) the highest GHG emissions contributor is Eastern and South-Eastern Asia with 1.2 billion tons of Carbon Dioxide Equivalent (CO2e), Latin America and the Caribbean 0.909 billion tons of $\mathrm{CO} 2 \mathrm{e}$, Sub-Saharan Africa 0.768 billion tons of $\mathrm{CO2e}$, and the lowest Northern Africa and Western Asia 0.156 million CO2e. The highest contributors in Sub-Saharan Africa are Ethiopia (96 million tons of CO2e) Sudan (72.5 million tons of CO2e), Nigeria (64.2 million tons of CO2e), South Sudan (43 million tons of CO2e) and Kenya (37.1 million tons of CO2e). Egypt is considered one of the countries that are vulnerable to $\mathrm{CC}$ impact because it is located in a region that falls between semi-arid and arid conditions, where $94.5 \%$ of Egypt total area is desert. The $5.5 \%$ of the area is populated with 95 million inhabitants that are located along the River Nile and the coastal area. In
Egypt, current annual average temperatures increase from about $20^{\circ} \mathrm{C}$ on the Mediterranean coastline to $24^{\circ} \mathrm{C}$. The projected increase towards 2030 there will be an increase by $1.0^{\circ} \mathrm{C}$ to $1.27^{\circ} \mathrm{C}$ using the forecast models RCP4.5 and RCP8.5 median ensemble, while the projected 2050 increase range from $1.64^{\circ} \mathrm{C}$ to $2.33^{\circ} \mathrm{C}$ using the forecast models RCP4.5 and RCP8.5 median ensemble (USAID fact sheet, 2015).

\section{Source of data and study area of the research question}

The objective of this study is to assess the impact of climatic variables on the technical efficiency of the cereals production of rice, wheat and maize for the most significant five producing governorates in Egypt for the period of 2000 to 2009 collected from the ministry of agriculture and land reclamation, economic affairs sector.

\section{The objective and contribution of the research paper}

This objective will be achieved through using panel frontier model to assess the impact of average maximum temperature, humidity and solar radiation on the technical efficiency of the highest cereals producing governorates (Behera, Gharbia, Kafr-Elsheikh, Dakahlia, and Sharkia). The contribution of this work is twofold: first, it focuses on the Egyptian agricultural, in contrast to the predominant literature, developing countries have not received much attention. Second, we compare efficiency scores among different governorates to propose suitable policies that match their needs.

\section{Literature review}

CC impacts in Africa has become a reality (Besada et al., 2009). The warming of Africa is very likely to be severe than in other regions (Gemeda and Sima, 
2015). Studies assessing CC impacts found that Africa is the most vulnerable in the world due to poor adaptation practices and high vulnerability (World Wide Fund For Nature, 2006; Clements, 2009; Niang et al., 2014). The low adaptive capacity at the financial, technical and institutional level caused that African countries are the most affected (Rose, 2015). Taking into account that agriculture is the most significant economic sector in Africa with the largest employment share of $60 \%$ (Awojobi and Tetteh, 2017). The more prolonged and severe droughts in Eastern Africa; increased floods in Western Africa; deforestation in equatorial Africa; and increased acidity across Africa's southern coast together with climate extreme events will have severe impacts on food security, health, water and energy security, which at the end will weaken African's potential to grow and develop. CC impacts in Ethiopia, Kenya, and Somalia shown were influenced by persistent droughts and losses of livestock where the majority of people are dependent on livestock for their livelihood (Besada and Sewankambo, 2009). For instance, Collomb (1999) predicted that by 2050, food production needs to be increased by quintuple in Africa, double in Asia, and almost double in Latin America.

In the northern part of the Mediterranean, a decrease in rainfall during the summer that is partially recovered during the winter by precipitation increase. In the central Mediterranean, periods of droughts are increased for one month, beginning one week earlier and finishing 3 weeks after. These changes have impacts on all economic activities such as agriculture, energy, tourism and environmentally through affecting the natural ecosystems. The results of the analysis show that in the case of agriculture, cultivated autumn and winter seasons are not affected or an increase in production. While in the case of summer crops a significant fall of yield was indicated (Giannakopoulos, 2009).

Berg et al. (2013) used agro-DGVM model (Dynamical Global Vegetation Model) driven by projections from several climate models and two (Special Report on Emissions) SRES scenarios to assess CC influences on possible C4 crop productivity in Africa and India for the period 1960 to 2100 . The authors distinguish the impact of rising $\mathrm{CO} 2$ emissions. They adopted transient simulations by the climate model outputs: to ensure the analysis consistency regardless of regional biases, investigate yield change using bioclimatic basis rather than geographical basis. The results of the analysis show a decreased average productivity of millet crop, which is considered an important staple crops in those regions, by $-6 \%$ (projections range from $-29 \%$ to $+11 \%$ ). The overall effect is yield decrease over the Equatorial and Temperate Köppen zones; significant inconsistencies change of yields that arise in Arid Köppen zones because of uncertainty in precipitation projections compared with climate models. Finally, the authors have concluded that climatic impacts put more pressure to achieve food security in developing countries in the Tropics, and these impacts can be alleviated through adopting adaptation practices and best farming practices. Deryng et al. (2011) used a global crop model, PEGASUS 1.0 (Predicting Ecosystem Goods and Services Using Scenarios) that incorporates the different indicators of planting dates, cultivar choices, type of irrigation and fertilization of the crop yield for maize, soybean, and spring wheat, in addition to climate indicators. The results of the model are consistent with global data. Additionally, the used planting and harvesting dates are found to be within crop calendar 
observations of almost $75 \%$ of the total crop-harvested areas. The authors found that variations in the temperature and rainfall lead to yield reduction, which as predicted by global climate models for the 2050s considering planting and harvesting dates remain unchanged. While adopting adaptation strategies for planting dates and choosing suitable cultivars can help increase yield in temperate regions and evades $7-18 \%$ of global losses.

CC influences different aspects of the economy from infrastructure, health, ecosystem, food and water security, to displacement. Logistical infrastructure like roads and bridges and services infrastructures like power and water stations are impacted due to flood, landslides and heavy rainfalls. The previous literature has shown evidence on the consequences of extreme climate change-induced events that influence road networks in Africa in for food security purposes (Cervigni et al., 2016). In different African countries like those that Ethiopia, Uganda, Ghana, and Tanzania have gone through drought events which affected their dams and caused a reduction in the hydropower generation. For the case of human health, CC increases the occurrence and gravity of disease outbreaks.

\section{Methodology}

There are two main approaches extensively used in the literature to measure technical efficiency: parametric SFA and non-parametric DEA. To take care of the identification problem caused by non-parametric models, SFA is used as an alternative. The SFA approach, was commenced simultaneously by (Aigner et al., 1977), makes a distinction between exogenous shocks outside the control and inefficiency of the firm. In contrast to DEA, SFA takes into account random noise and allows for conventional tests of hypotheses. Additionally, SFA requires the specification of a functional form for the production function and a distributional assumption for the inefficiency term. Agricultural production is stochastically determined since it is affected by climatic changes, and the agricultural production literature is likely affected by measurement and variable omission errors (Oude Lansink et al., 2002), choosing a robust model is vital to consider these problems.

The common characteristic among all the frontier models is that the intercept has not been changed over productive units, which leads to misspecification in the existence time-invariant unobservable factors, which cause that these factors may be captured by the inefficiency term, resulting in producing biased estimates. Greene (2005) has introduced a model to solve this issue using a time-varying stochastic frontier model with unit-specific intercepts. In contrast with the previous models helps to distinguish time-varying inefficiency from unit specific time-invariant unit heterogeneity. For this reason, Greene named these models as True Fixed Effects (TFE) or True random effects (TRE). While the estimation of the TRE specification is computationally simple using simulation-based techniques, the ML estimation of the TFE model needs to solve two main challenges related to nonlinear panel data models estimation. The first is related to a computational challenge because of the large size of the parameters space. However, Greene [2005a, 2005b] has provided evidence that a Maximum Likelihood Dummy Variable (MLDV) methodology is feasible in the case of a large number of nuisance parameters $\alpha_{i}(N>1000)$. The second challenge is the incidental parameters problem, which is an inferential problem that is a result of a larger number of units, compared to the length of the 
panel. We adopt a True Fixed Effects (TFE) stochastic production function:

$$
\begin{aligned}
& y_{i t}=\alpha_{i}+X_{i t}^{\prime} \beta+\varepsilon_{i t} \\
& \varepsilon_{i t}=v_{i t}-u_{i t}
\end{aligned}
$$

where $y_{i t}$ denotes the level of output of governorate $\mathrm{i}$ at time $\mathrm{t}, X_{i t}$ is a vector of input costs of the $\mathrm{i}$-th governorate at time $t . \beta$ is a vector of parameters to be estimated. Component $\alpha_{i}$ in equation (1) is the random governorate specific effect, this specification allows to disentangle time-varying inefficiency from unit specific time invariant unobserved heterogeneity. The error term $\varepsilon_{i t}$ in equation (2) can be decomposed into two components. The first component, $v_{i t}$ is a normally distributed disturbance capturing the random variation in output due to statistical noise that occurs due to the unintended omission of relevant variables from vector $X_{i t}$; errors (measurement and approximation) associated with the choice of the functional form; unexpected stochastic the control of the industry. Component $v_{i t}$ is usually assumed to be symmetric, independent and identically distributed as $\mathrm{N}\left(0, \sigma_{v}^{2}\right)$. The second component $u_{i t}$ is a one-sided, non-negative random variable, representing the stochastic shortfall of the i-th governorate output from its production frontier, assumed to be independently distributed following a truncated normal with mean $\left(Z_{i t} \delta\right)$ and variance $\sigma^{2}, Z_{i t}$ is a vector of exogenous variables associated with the inefficiency of production of governorates over time distribution (4). Compared with previous literature on panel stochastic frontiers, this specification can differentiate unit specific time invariant unobserved heterogeneity and time varying inefficiency. To this end, TFE model is specified and is estimated using a Simulated Maximum Likelihood (SML). The technical inefficiency effects model:

$u_{i t}=\delta Z_{i t}+\xi_{i t}$

where $u_{i t}$ is the technical inefficiency for governorate $i$ at time $t$, obtained from the stochastic frontier model and $\xi_{i t}$ is the error term. Selection of $Z_{i t}$ variables is based on previous literature and data availability. The method of estimation is the simulated maximum likelihood for simultaneous estimation of the stochastic frontier model and the technical inefficiency model following [58]. We have specified a dynamic panel frontier models for cereals crops which are (wheat, maize, rice) for the ith governorates (Behera, Gharbia, KafrElsheikh, Dakahlia, and Sharkia) for specified $\mathrm{T}$ time periods based on data availability. The frontier and efficiency models specifications for the selected cereal crops are presented in Table 1. Logarithmic transformations of variables are used and we followed a one-step estimation of the likelihood function.

\begin{tabular}{|c|c|}
\hline Wheat & $\begin{array}{c}y_{i t}=\alpha_{i}+\beta_{1} \text { AREA }_{i t}+\beta_{2} \text { fertilizers }_{i t}+\beta_{3} \text { Pesticides }_{i t}+\beta_{4} \text { labor }_{i t}+\beta_{5} y_{i t-1} \\
u_{i t}=\delta_{1} \text { MaxTemp }_{i t}+\delta_{2} \text { Humidity }_{i t}+\delta_{3} \text { SolarRad }_{i t}+\xi_{i t}\end{array}$ \\
\hline Rice & $\begin{array}{c}y_{i t}=\alpha_{i}+\beta_{1} \text { AREA }_{i t}+\beta_{2} \text { fertilizers }_{i t}+\beta_{3} \text { Pesticides }_{i t}+\beta_{4} \text { labor }_{i t}+\beta_{5} y_{i t-1} \\
u_{i t}=\delta_{1} \text { MaxTemp }_{i t}+\delta_{2} \text { Humidity }_{i t}+\delta_{3} \text { SolarRad }_{i t}+\xi_{i t}\end{array}$ \\
\hline Maize & $\begin{array}{c}y_{i t}=\alpha_{i}+\beta_{1} \text { AREA }_{i t}+\beta_{2} \text { fertilizers }_{i t}+\beta_{3} \text { Pesticides }_{i t}+\beta_{4} \text { labor }_{i t}+\beta_{5} y_{i t-1} \\
u_{i t}=\delta_{1} \text { MaxTemp }_{i t}+\delta_{2} \text { Humidity }_{i t}+\delta_{3} \text { SolarRad }_{i t}+\xi_{i t}\end{array}$ \\
\hline
\end{tabular}

Table 1 Frontier models specification 


\section{RESULTS AND DISCUSSION}

The present empirical application aims at studying the impact of climate conditions on the technical efficiencies of producing cereal crops in Egypt using SFA approach applied on a panel dataset obtained from Ministry of Agriculture and the Central Laboratory for Agricultural Climate. Our sample consists of five governorates for the period 2000-2009 yielding 50 observations. The analysis was carried out using the econometric software Stata 11.2. The data are transferred to logs to have a more straightforward interpretation of the estimated parameters as elasticities. The SFA model estimates are obtained with a Cobb-Douglass functional form as presented in Table 1. The dependent variable $\left(y_{i t}\right)$ is the production quantity in tons per year of the identified crop. The crops used in the analysis are necessary for food security in Egypt since they are considered a staple food. The inputs includes: $\left(x_{1 i t}\right)$ area of the selected crops in the targeted governorates measured in acres; $\left(x_{2 i t}\right)$ is the cost of fertilizers measured as Egyptian pounds per acre; $\left(x_{3 i t}\right)$ is the cost of pesticides measured as Egyptian pounds per acre; $\left(x_{4 i t}\right)$ represent the cost of labor hours per acre; $\left(y_{i t-1}\right)$ is the lagged production quantity in terms of tons per lagged year.

Results of the estimated stochastic frontier models are presented in Table 2. Results of the production elasticity estimates indicate that, for all governorates, the cultivated area has the largest positive effect on the quantity produced. In the case of the rice model, cultivated land, labor and fertilizers are found to have statistically significant influence; lagged rice production has a negative impact on current production because of the government policy to minimize water resources consumption. In the case of the Maize model, cultivated area and fertilizers are found to be relevant. For the wheat model, the cultivated area and lagged production are the relevant factors affecting production. Other factors in the three models were not statistically significant because these input factors are subsidized since the government provides cereal farmers, especially wheat producers, with subsidized inputs quantities. These results are compatible with (Elasraag, 2015) that identified these factors of production are the most productive in Egypt's agriculture sector. For the technical inefficiency equations for the three models, the climatic indicators were found to be relevant in causing a problem of increasing the technical inefficiency and as a result preventing achieving the maximum potential of producing these crops.

\section{Standard errors in parenthesis}

According to Table 3, TE scores for the three cereal crops in the selected governorates are calculated as an outputoriented measure following (Battese and Coelli, 1995). The average technical efficiency score is for wheat and maize is above $90 \%$ in Kafr-Elsheikh, Beher, and Gharbia, while Dakahlia is more technically efficient in Maize production only, and this is expected since these governorates are the biggest wheat producers. The average technical efficiency score is for rice range from $80 \%$ to $85 \%$ along with the four governorates yet Dakahlia governorate minimum technical efficiency is $80 \%$, which is higher than the minimum levels in other governorates. These results indicate that if these governorates effectively use available resources and at the current technology, it will be able to increase the output by $10 \%$ on average. Improving technical efficiency allows reducing production costs and increases competitiveness, which can help farmers face changing conditions and 
unfortunate economic circumstances. Climatic variables are found to be relevant in affecting the technical efficiency and this call for adopting new agricultural practices that are adaptive to these climate induced-events. As in the case of poor climatic circumstances, farm margins may be squeezed due to the loss in production or affect crop quality. In this line, improving technical efficiency can help farmers endure times of hardship. A strategy based on increasing the skills of farmers is relevant as well as improving local and regional markets infrastructure and transportation networks in Egypt. However, improving technical efficiency is not sufficient to be more competitive and economically efficient. Farmers also need to improve their allocative efficiency, an essential component of economic efficiency. Future extension of this work will concentrate on the analysis of allocative efficiency for agricultural subsectors, the second component of economic efficiency and the study total factor productivity and its components for each group.

Table 2. Parameter estimates of the stochastic frontier models

\begin{tabular}{lccc}
\hline & Wheat & Maize & Rice \\
\hline Cultivated area & $0.726^{\star \star \star}$ & $0.973^{\star \star \star}$ & $1.074^{\star \star \star}$ \\
& $(0.050)$ & $(0.025)$ & $(0.008)$ \\
\hline Fertilizers & 0.020 & $0.054^{\star}$ & $0.049^{\star \star \star}$ \\
& $(0.020)$ & $(0.030)$ & $(0.009)$ \\
\hline Pesticides & 0.010 & -0.025 & 0.036 \\
\hline Capital & $(0.010)$ & $(0.027)$ & $(0.032)$ \\
\hline \multirow{2}{*}{ Labor } & 0.010 & & 0.026 \\
\hline \multirow{2}{*}{ Seeds } & $(0.023)$ & - & $(0.074)$ \\
\hline Lagged & -0.024 & 0.011 & $0.081^{\star \star}$ \\
Production & $(0.020)$ & $(0.073)$ & $(0.033)$ \\
\hline Returns to scale & -0.012 & 0.038 & $-0.075^{\star \star \star}$ \\
\hline
\end{tabular}

\begin{tabular}{|c|c|c|c|}
\hline \multicolumn{4}{|c|}{ Parameter estimates of the inefficiency model } \\
\hline Average Max. Temperature & - & $\begin{array}{l}2.341^{\star \star \star} \\
(0.221)\end{array}$ & $\begin{array}{l}1.017^{\star \star \star} \\
(0.202)\end{array}$ \\
\hline Humidity & $\begin{array}{c}0.406^{\star \star \star} \\
(0.104)\end{array}$ & $\begin{array}{c}0.973^{\star \star \star} \\
(0.191)\end{array}$ & $\begin{array}{l}0.331^{\star *} \\
(0.155)\end{array}$ \\
\hline Log pseudolikelihood & 100.464 & 108.689 & 108.672 \\
\hline
\end{tabular}


Table 3. Summary statistics for technical efficiency scores

\begin{tabular}{llccc}
\hline Behera governorate & Mean & Std. Dev. & Min & Max \\
\hline Wheat model & 0.967 & 0.013 & 0.950 & 0.989 \\
\hline Maize model & 0.955 & 0.047 & 0.878 & 0.999 \\
\hline Rice model & 0.810 & 0.018 & 0.779 & 0.835 \\
\hline Gharbia governorate & & & & \\
\hline Wheat model & 0.985 & 0.015 & 0.955 & 0.999 \\
\hline Maize model & 0.956 & 0.045 & 0.862 & 0.999 \\
\hline Rice model & 0.814 & 0.030 & 0.753 & 0.846 \\
\hline Kafr-Elsheikh governorate & & & & \\
\hline Wheat model & 0.905 & 0.025 & 0.861 & 0.937 \\
\hline Maize model & 0.934 & 0.043 & 0.872 & 0.999 \\
\hline Rice model & 0.853 & 0.051 & 0.764 & 0.894 \\
\hline Dakahlia governorate & & & & \\
\hline Wheat model & 0.967 & 0.019 & 0.947 & 0.999 \\
\hline Maize model & 0.988 & 0.012 & 0.972 & 0.999 \\
\hline Rice model & 0.831 & 0.024 & 0.776 & 0.851 \\
\hline Sharkia governorate & 0.989 & 0.008 & 0.972 & 0.999 \\
\hline Wheat model & 0.860 & 0.027 & 0.809 & 0.888 \\
\hline Maize model & & & & \\
\hline Rice model & & & & \\
\hline & & & & \\
\hline
\end{tabular}

\section{Conclusions}

The agricultural sector constitutes a large portion of the economies in Africa, which can help in solving major issues like malnutrition and hunger. $\mathrm{CC}$ has been identified as a significant threat especially to vulnerable regions especially Africa. Two main factors affect agricultural growth namely labor and agricultural land together with other factors that can help to boost food production; the development of secure market infrastructure and a transportation network that facilitates the supply of food. All these factors are impacted by climate change, which leads to a negative impact on food security. Since CC may cause a reduction in agricultural production, impact negatively logistical infrastructure which 
may reduce access to food, a loss in natural resources impacting the sustainability of using these resources, and finally changing the cropping pattern of a region affecting the needed nutrition requirements of these regions.

\section{Recommendations}

Based on the results, this information could help policymakers understand how to apply any new policies. For example, making new investment plans for introducing climate-smart technologies and adopting new production practices that may help increase farms' technical efficiencies that in turn will help increasing agricultural output and reduce the variability of yields. Additionally, improving local markets infrastructure and logistics, which will help to smooth the supply of food and facing international markets volatilities. Considering that family farming which represents the majority of all farms in Egypt, improving their technical efficiency allows reducing production costs and improving competitiveness that can help them face fluctuating market conditions and economic hardships. As climate impact on agriculture is intensifying, Egyptian agricultural policies needs to be developed that technically support farmers through training to improve their skills to face these effects, minimizing carbon emission from agriculture the recycling of agricultural waste instead of burning it. Use new varieties of cereal crops that are more resistant to climate impact. Develop markets for carbon credits to regulate the right to pollute. Promote sustainable use of natural resources like the current government initiatives of reducing rice and sugar cane crops cultivated areas to reduce water consumption and adoption of advanced irrigation systems that efficiently use water.

\section{REFERENCES}

Aigner, D., C.A.K. Lovell and P. Schmidt (1977). Formulation and estimation of stochastic frontier production functions models. Journal of Econometrics 6: 21-37.

Awojobi, O. and J. Tetteh (2017). The impacts of climate change in Africa: a review of the scientific literature. Journal of international academic research for multidisciplinary, 5 (11): 39-52.

Battese, G. and T. Coelli (1988). Prediction of firm-level technical efficiencies with a generalized frontier production function and panel data. Journal of Econometrics 38: 387-399.

Battese, G. and T. Coelli (1992). Frontier production functions, technical efficiency and panel data: with application to paddy farmers in India. Journal of Productivity Analysis 3 (1/2): 153-169.

Battese, G. and T. Coelli (1995). A model for technical inefficiency effects in a stochastic frontier production function for panel data. Empirical Economics 20: 325-332.

Berg, A., N. de Noblet-Ducoudre, B. Sultan, $M$. Lengaigne and $M$. Guimberteau (2013). Projections of climate change impacts on potential C4 crop productivity over tropical regions. Agricultural and Forest Meteorology, 170: 89-102.

Besada, H. and N. Sewankambo (2009). CIGI Special Report: Climate Change in Africa: Adaptation, Mitigation and Governance Challenges. Available at: https://www.cigionline.org/sites/ default/files/climate change in africa 3.pdf 
Cervigni, R., A. M. Losos, P. Chinowsky and J. L. Neumann (2016). Enhancing the climate resilience of Africa's Infrastructure: the roads and bridges sector (No. 110137) (pp. 1-0). The World Bank.

Clements, R. (2009). economic-cost-ofclimate-change-in-africa.

Climate Change Risk Management in Egypt (CCRM), 2013.

Collomb, P. (1999). Une voie étroite pour la sécurité alimentaire d'ici a 2050. FAO Economica, Paris.

Deryng, D., W. J. Sacks, C. C. Barford and N. Ramankutty (2011). Simulating the effects of climate and agricultural management practices on global crop yield. Global Biogeochemical Cycles, 25, GB2006, doi:10.1029/2009GB003765.

Elasraag, Y., Economics of Wheat in Egypt. Published PhD dissertation, 2015. Technical University of Madrid. Available at: http://oa.upm.es/39024/1/YAHIA HAMI D AMIN ELASRAAG.pdf

Food and Agricultural Organization (FAO) report (2016). The State of Food and Agriculture: Climate change, Agriculture, and food security. Available at: http://www.fao.org/3/ai6030e.pdf

Food and Agricultural Organization. (FAOSTAT), (2018). Available at: http://www.fao.org/ faostat/en/

Food and Agricultural Organization, Global Early Warning System, (FAOGIEWS), 2018.

Gemeda, D. O. and A. D. Sima (2015). The impacts of climate change on African continent and the way forward. Journal of Ecology and the Natural Environment, 7(10): 256-262.

Giannakopoulos, C., P. Le Sager, M. Blndi, M. Moriondo, E. Kostopoulou and C.M. Goodess (2009). Climatic changes and associated impacts in the Mediterranean resulting from a $2^{\circ} \mathrm{C}$ global warming. Global and Planetary Change, 68: 209-224.

Greene, W. (2005a). Reconsidering heterogeneity in panel data estimators of the stochastic frontier model. Journal of Econometrics 126, 269-303.

Greene, W. (2005b). Fixed and random effects in stochastic frontier models. Journal of Productivity Analysis 23: 732.

International Food Policy Research Institute and World Food Program, (IFPRI-WFP), (2013). Tackling Egypt's Rising Food Insecurity in a Time of Transition. Joint IFPRI-WFP country policy note.

Niang, I., O. Ruppel, M. Abdrabo, A. Essel, C. Lennard, J. Padgham and P. Urquhart (2014). Africa. In: Climate change 2014: impacts, adaptation and vulnerability. Contribution of Working Group II to the Fifth Assessment Report of the Intergovernmental Panel on Climate Change. Cambridge University.

Olila, D.O. and V. V. Wasonga (2016). Nexus between Climate Change and Food security in the East Africa Region: An Application of Autoregressive Modelling Approach. Invited Paper Presented at the Fifth African Higher Education Week and Ruforum Biennial Conference, 17 - 21 October, 2016, Cape Town, South Africa.

Oude Lansink, A., K. Pietola and S. Bäckman (2002). Efficiency and productivity of conventional and organic farms in Finland 1994-1997. European Review of Agricultural Economics 29: 51-65.

Rose, R. M. (2015). The Impact of Climate Change on Human Security in the 
Sahel Region of Africa. Donnish Journal of African Studies and Development, 1(2): 9-14.

Singh, A. and B. M. Purohit (2014). Public Health Impacts of Global Warming and Climate Change. Peace Review, 26(1): 112-120.

https://doi.org/10.1080/10402659.2014. 876326

Synthesis of Experiences and Recommendations. UNDP report, 2018. Climate Change Adaptation in Africa. Available at: http://www.fao.org/giews/earthobserva tion/asis/index 1.jsp? lang=en
USAID fact sheet (2015). Climate Change Information Fact Sheet Egypt.

World Bank. (2016). Shock Waves: Managing the Impacts of Climate Change on Poverty.

World Wide Fund For Nature. (2006). Climate change impacts on East Africa. World Wide Fund For Nature.

Zomer, R. J., H. Neufeldt, J. Xu, A. Ahrends, D. Bossio, A. Trabucco, M.V. Noordwijk and M. Wang (2016). Global Tree Cover and Biomass Carbon on Agricultural Land: The contribution of agroforestry to global and national carbon budgets. Scientific Reports । 6:29987 | DOI: 10.1038/srep2998. 
تقييم تأثير المناخ على الزراعة المصرية: نهج تحليل الكفاءة القنية للانتاج

$$
\text { فادي عبد الراضي }
$$

قسم الاقتصاد الزراعي، جامعة القاهرة، مصر

الملخص

يخلص التقرير الصادر عن الهيئة الدولية المعنية بتغير المناخ 2018 (IPCC) حول الآثار المترتبة على ارتفاع درجات الحرارة بمقدار (0, (1) درجة إلى أن الآثار المتوقعة لزيادة درجة الحرارة هي أكثر أهمية مما كان

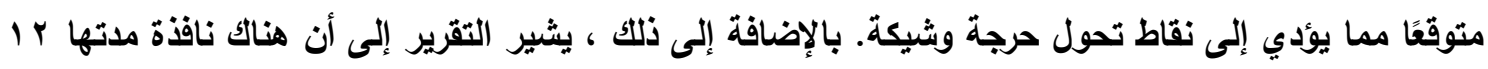

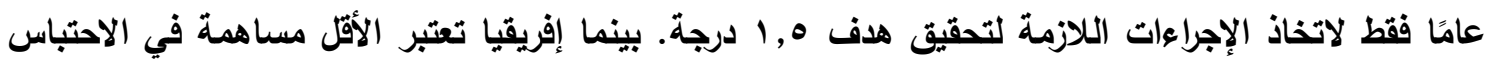

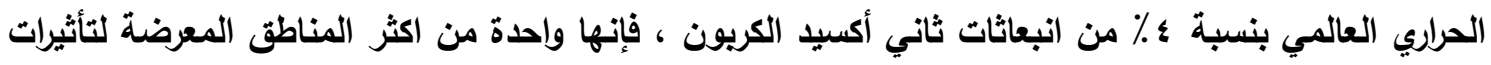
تغير المناخ.

تهاف هذه الدراسة إلى تقييم المتغيرات المناخية المختلفة على الكفاعة الفنية لإنتاج محاصيل الحبوب في أكبر خمس محافظات منتجة في مصر. تم تحقيق هذا الهذف من خلال استخدام نموذج دوال الكفائة الانتاجية لتقييم تأثير متوسط درجة الحرارة القصوى والرطوية والإثعاع الثمسي على المحافظات المنتجة للقمح والأرز

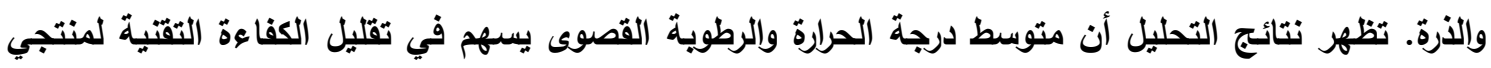
الحبوب. 
